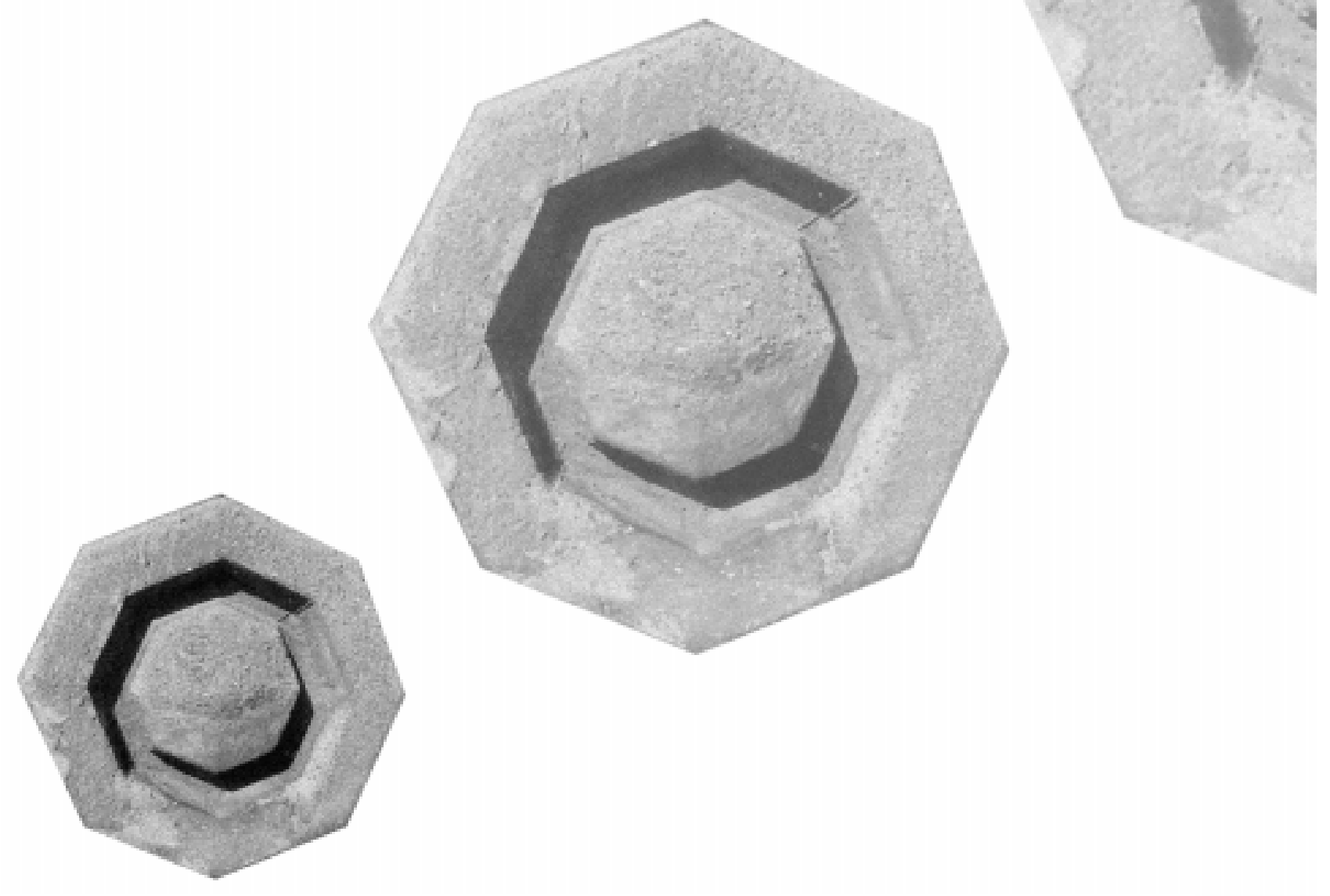




\section{Thomas Lindley: um viajante fala de doenças e dos seus enfrentamentos, no início do século XIX}

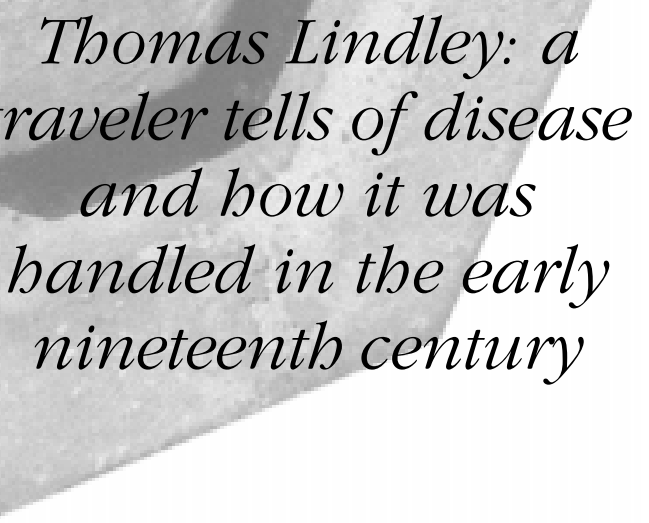

Ó, A. A. do: Thomas Lindley: um viajante fala de doenças e dos seus enfrentamentos, no início do século XIX'.

História, Ciências, Saúde-Manguinhos, vol. 11(1): 13-31, jan.-abr. 2004.

Thomas Lindley, comerciante inglês, foi preso como contrabandista na Bahia do início do século XIX. Tendo sido confundido com um médico, atuou como tal enquanto ali esteve. Ao voltar à Inglaterra publicou seu diário. O presente estudo é uma tentativa de destacar suas referências aos modos pelos quais os colonos daquela época e daquele lugar viviam a experiência da doença e dos tratamentos médicos.

PALAVRAS-CHAVE: viajantes, medicina colonial, história cultural.

Ó. A. A. do: 'Thomas Lindley: a traveler tells of disease and how it was handled in the early nineteenth century'.

História, Ciências, Saúde-Manguinhos, vol. 11(1): 13-31, Jan.-Apr. 2004.

Thomas Lindley, an English businessman, was arrested for smuggling in Babia at the beginning of the nineteenth century. He was mistaken for a doctor and ended up serving as one while there. Upon returning to England, he published his diary. This study takes a close look at his references to how settlers back then and there experienced disease and medical treatment.

KEYWORD: travelers, colonial medicine, cultural bistory
Alarcon Agra do Ó

Departamento de História e Geografia Centro de Humanidades -

Universidade Federal de Campina Grande Rua Manoel Alves Oliveira, 159. Bloco 10B/001 - Catolé. 58105-600 Campina Grande - PB Brasil 


\section{A questão}

$\mathrm{O}$

s viajantes talvez estejam cansados, tantas e tão variadas questões

já lhes foram postas. Não estão, certamente, esgotados: frente às indagações da história, sempre novas mesmo quando dirigidas a materiais já escavados por muitos, os viajantes ainda parecem ser um mundo a explorar. Certamente eles têm muito a dizer aos pesquisadores da história dos costumes, em especial, pela riqueza dos seus registros e pelas possibilidades de investigação neles sugeridas.

No presente texto tentaremos colocar em cena a pronúncia de um deles acerca de uma questão específica. Interessa-nos descrever os modos pelos quais Thomas Lindley retratou, na sua Narrative of $a$ Voyage to Brazil, os usos e costumes da então colônia portuguesa, no que diz respeito às experiências das doenças e das terapêuticas.

Nos últimos anos, o estudo histórico das práticas médicas tem chamado a atenção de um sem-número de pesquisadores, e diversos trabalhos têm sido produzidos - principalmente em programas de pós-graduação - acerca dos meandros desse campo. As ciências sociais em geral têm se mostrado bastante porosas a investigações sobre as formas pelas quais, em outros tempos, as sociedades organizaram sua percepção quanto à saúde e ao adoecimento e quanto às práticas técnicas que as circunscreveram e atravessaram (cf., p. ex., Canesqui, 1997; Rodrigues, 1999). No presente estudo alguns desses trabalhos serão referidos, sem que no entanto se tenha praticado uma efetiva revisão bibliográfica.

O estudo aqui apresentado foi produzido em meio a um esforço de investigação mais amplo, no qual se busca entender as formas pelas quais, no século XIX, foram produzidas e postas em circulação representações acerca das relações entre a saúde e a doença. O objetivo dessa investigação maior é a composição de um quadro de referências que permita pensar, dentro dos seus limites, como a saúde e a doença, na história do Brasil, foram e são constituídas não apenas como 'fatos médicos', mas como campos de invenção de possibilidades para o ser dos brasileiros.

Em linhas gerais, o campo teórico em que essa investigação se situa é aquele enunciado por Robert Darnton(1986), quando este propõe uma abordagem histórica voltada para o estudo das formas pelas quais as pessoas, imersas na sua experiência cultural singular, interpretam o seu mundo, conferem a ele sentido e lhe infundem emoção. Para entender como isso se dá, deve-se, ainda segundo Darnton, investigar as gramáticas sociais a partir das quais os sujeitos, em meio a pronúncias e silêncios, pensam e organizam significativamente o seu mundo, reinventando-o e a si mesmos no seu diálogo com os códigos culturais. 


\section{Thomas Lindley e seu livro}

Thomas Lindley foi o primeiro inglês a escrever sobre o Brasil, no século XIX. Ele esteve aqui por um curto período de tempo, no início daquele século, quando, aportando na Bahia, foi preso como contrabandista. Na opinião de Américo Jacobina Lacombe (autor do texto de orelha da edição brasileira da Narrative, de 1969), Lindley já deveria ter vindo ao Brasil outras vezes. Afinal, nessa obra, "no correr de uma descrição da Bahia, faz uma comparação com o Rio de Janeiro enunciando um juízo pessoal. Como nessa viagem o Rio não é sequer avistado, segue-se que o nosso autor não podia ser marinheiro de primeira viagem" (Lacombe, 1969). Quando conseguiu sua liberdade, após o episódio de 1802/1803 e já em Londres, Lindley publicou seu diário, em que relatou "sua viagem, a captura de seu barco, sua prisão e a da tripulação", descrevendo em meio a isso os "habitantes da cidade de Salvador e Porto Seguro, e acrescentando informações geográficas de interesse para a navegação" (Pinho, 1969, p. 7; Quintaneiro, 1995, p. 218).

No Prefácio à mesma edição brasileira de 1969, Wanderley Pinho nos dá algumas informações a respeito da obra de Lindley. Por ele sabemos, por exemplo, que a primeira edição do livro, em 1805, em Londres, foi sucedida por uma tradução francesa e uma alemã, ambas em 1806; em 1808 sairia a segunda edição inglesa. O trabalho do viajante inglês foi elogiado por Afonso d'E. Taunay, Capistrano de Abreu e Eduardo Prado, e vários autores se valeram de suas informações para a feitura de suas obras (Andrew Grant chegou a copiar, sem citar, inúmeros trechos de Lindley em History of Brazil). Para todos eles o livro de Lindley, apesar dos seus 'comentários depreciativos' sobre o Brasil - atribuídos por Taunay, segundo Pinho (op. cit., pp. 7-9), "às expansões do mau humor de um contrabandista perseguido pelas autoridades" —, seria de "agradável leitura" e traria "muita cousa interessante" para o estudioso da nossa história .

Wanderley Pinho ressalta, por outro lado, a ausência de grandes registros sobre a figura de Thomas Lindley, bem como de sua biografia. A pesquisa empreendida pelo autor em "bibliografias" e "enciclopédias inglesas" pouco ou nada informa sobre esse personagem. Sua marca foi o seu texto, o qual, diz Pinho (op. cit., pp. 9-10), "dado o desconto do estado de espírito do autor", é um trabalho " em seu aspecto geral honesto e muito informativo".

\section{Thomas Lindley viajante}

Um entendimento mais ampliado do texto de Lindley pode ser alcançado se considerarmos as condições gerais em que ele foi produzido. Não pretendemos esgotar as possibilidades de uma tal contextualização, mas cremos ser importante e mesmo interessante apontar algumas facetas daqueles anos. 
${ }^{1}$ Segundo Alencastro (1997b, p. 34), "Nos anos 1870, metade da população masculina da corte era estrangeira, vinda principalmente de Portugal". O autor ainda registra que, a partir dos anos 1840 , com o casamento de dom Pedro II, a Corte foi tomada por artistas italianos e que, na década seguinte, a corrida em busca das minas de ouro na Califórnia também fez com que muitos estrangeiros viessem ao Brasil, já que Bahia e Rio de Janeiro, em especial, eram pontos de passagem obrigatórios das rotas marítimas de então. Os anos 1880 veriam o início da imigração européia, especialmente direcionada para São Paulo (op. cit., pp. 41, 51 e 57). Gobineau, nos anos 1870, também abordou a chegada de estrangeiros ao Brasil (Raeders, 1996, esp. pp. 83-7).
Uma primeira questão a ser ressaltada diz respeito ao fato de que, até a primeira década do século XIX, a presença de estrangeiros no Brasil era dificultada pela administração colonial, que acirrara esse controle a partir do século XVIII. Sobre esse assunto Pedro M. Campos cita Andrew Grant, que publicou em 1809 a History of Brazil, mencionada anteriormente, na qual está registrada uma crítica “à ciumenta e iliberal política, que em todos os tempos caracterizou o governo do Brasil, no concernente ao seu intercâmbio com estrangeiros". Para Grant (apud Campos, 1985, p. 49), a prevenção excessiva de Lisboa contra os não-portugueses no Brasil acabara por fazer com que tivesse sido "difícil, até o momento, a obtenção de dados exatos relativamente às produções e ao comércio" da então colônia portuguesa. Certamente isso contribuiu para a construção, no imaginário europeu e norte-americano, de um fascínio especial pelo Brasil, o que estimularia muito a produção dos viajantes. Desde tempos imemoriais, como se sabe, a mitologia acerca do Novo Mundo era das mais férteis, e o sonho do Eldorado era apenas uma de suas manifestações (Quintaneiro, op. cit., p. 14; Manthorne, 1996, pp. 60-5).

Aquele momento específico da história, portanto, teve implicações na narrativa de Lindley. Assim, a partir do desejo de entender e expressar somente o que via e vivia, a fim de que sua experiência pudesse vir a ser traduzida convenientemente para os leitores ingleses, Lindley relatou uma série multiforme de estranhamentos mútuos entre ele e os naturais do Brasil — mas também de tentativas, de parte a parte, de aproximação. Ora, como se pode entender, os ingleses, a exemplo dos estrangeiros não-portugueses em geral, eram figuras raras na paisagem do Brasil do início do século XIX, e mesmo após a independência eram vistos como elementos estranhos na paisagem local, ainda que deva ser ressaltada a marcante "influência estrangeira continuamente manifestada após a abertura dos portos" (Alencastro, 1997a, p. 24). ${ }^{1}$ Disso decorria que os brasileiros os viam como seres admiráveis, com os quais se devia ter algum contato, mesmo a despeito dos eventuais constrangimentos causados pela diferença de costumes e pela barreira do idioma. Lindley relata seguidas vezes, no seu texto, ter sido visitado por pessoas que vinham a ele, formalmente, "apresentar seus respeitos", quando na realidade pareciam desejar apenas "satisfazer a sua curiosidade" (Lindley, [1805] 1969, p. 87).

Tal desejo de conhecimento também marcava os ingleses. Um isolamento demasiado longo cavara entre brasileiros e estrangeiros fossos largos, de transposição difícil mas sedutores; as diferenças serviam ora para justificar isolamentos, ora para estimular a curiosidade. Os contatos, quando haviam, se faziam em meio a muitas dificuldades, por falta de maiores referências ou de canais de diálogo mais consistentes. De parte a parte grassavam incompreensões, e não é de se estranhar, no relato de Lindley, a abundância de erros de grafia de topônimos e antropônimos, ou equívocos da população quanto à sua pessoa - o 
${ }^{2}$ Diz Mário G. Ferri (1975, p. 9): "O século XIX está marcado, em nossa história, por inúmeras visitas mais ou menos prolongadas, que ao nosso país fizeram ilustres personalidades, dentre os quais numerosos naturalistas." Ferri, recuperando informações coletadas originalmente pelo visconde de Taunay, apresenta uma lista de cerca de trinta viajantes, só entre os naturalistas. mais dramático deles tendo sido o entendimento de que nosso autor era um médico importante, uma vez que era inglês e portava, na sua bagagem, uma caixa de medicamentos (Quintaneiro, op. cit., pp. 25-8).

Também é oportuno pensar o significado das viagens, naquele período. Verificava-se então uma expansão notável nas viagens de europeus e norte-americanos, que partiam em direção a qualquer canto do planeta que lhes parecesse exótico e digno de conhecimento. Tais deslocamentos, naquela circunstância singular, não apenas se intensificavam como também se transformavam.

Até o século XVIII a viagem assumiu, para os ocidentais, um caráter formativo. Sabia-se que os indivíduos partiam para terras distantes por conta de seu temperamento; essas viagens eram consideradas ousadias de pessoas aventureiras. Os homens as viam como uma oportunidade de aprendizagem: o mundo era "uma grande escola; percorrê-lo contribuía para o amadurecimento do espírito e do intelecto e para a aquisição de um horizonte cultural indispensável à época moderna" (idem, ibidem, p. 15).

No fim do século XVIII, no entanto, a esse caráter edificante das viagens acrescentou-se o de preparação para se "conquistar, para o saber e o mercado, aquelas terras que a invenção do navio a vapor aproximava”. Não bastava mais conhecer o mundo; o importante era verificar, em todo lugar visitado, quais as suas possibilidades de inserção na nova ordem que o capitalismo industrial começava a implantar. Foi nesse contexto que Lindley viu ser criada, com a sua prisão, a possibilidade para uma observação cuidadosa daquela terra estranha e fascinante (idem, ibidem, pp. 16-7; Vergara, 1998).

Nesse cenário, o início do século XIX foi marcado por uma redescoberta da América, principalmente no que dizia respeito às áreas coloniais portuguesas. ${ }^{2}$ Para isso contribuíram os movimentos de descolonização que vinham ocorrendo desde o século anterior, as pressões napoleônicas contra a Inglaterra, que obrigavam os ingleses a tentar o estabelecimento de relações comerciais com zonas nãoeuropéias e, mais adiante, a instalação da Corte portuguesa no Rio de Janeiro, após 1808.

Considerando o que dissemos até aqui, não surpreende que o texto de Lindley, tenha obtido uma boa recepção na Europa, sendo sucessivamente editado e mesmo copiado. Talvez a explicação resida também, para além das qualidades intrínsecas da narrativa, no fato de que uma dimensão da sensibilidade européia no século XIX era a busca pelo pitoresco, pelo característico (Belluzzo, 1996, p. 18; Vergara, op. cit.).

Até meados do século XIX a sensibilidade frente à natureza estava centrada na possibilidade de uma leitura moralizante e didática das plantas, dos animais, das paisagens naturais (Manthorne, 1996, p. 60). Essa busca do fascinante estava vinculada à idéia de que a viagem, como vimos 
anteriormente, era uma oportunidade de educação da sensibilidade moderna: conhecer o diferente e o estranho era um modo de educar o olhar e estar no mundo, que então se imaginava adequado para aquele tempo (Quintaneiro, op. cit., p. 17; Vergara, op. cit.).

As narrativas de viagem contavam portanto com um público desejoso de conhecer as terras estranhas que estavam muito além de suas fronteiras (Soares, 2001). A sua leitura era, em certa medida, um movimento de conquista e exploração de locais distantes, ao mesmo tempo que serviam para colocar em perspectiva os ritmos e as intensidades do próprio lugar do leitor (Manthorne, op. cit.). O mercado editorial para os relatos - diários, relatórios comerciais e diplomáticos, tratados de história natural e geografia e roteiros turísticos - expandia-se continuamente. As obras eram rapidamente reeditadas e traduzidas para vários idiomas, transformando os leitores em viajantes especiais, caçadores furtivos de riquezas antes jamais imaginadas (Quintaneiro, op. cit., p. 18; Vergara, op. cit.).

É preciso ressaltar uma última questão, para a construção de um dispositivo para o exame do texto de Lindley. Diz respeito a uma característica dos textos dos viajantes, bem sintonizada com a sua época porque marcada pela emergência do indivíduo moderno, que reverbera de forma intensa no texto de Lindley: o fato de que os viajantes do século XIX falavam a partir de um lugar criteriosamente estabelecido, a sua experiência pessoal. O relato de Lindley trata do que ele viveu como indivíduo histórico singular, e a confiabilidade do texto residiria, para a sensibilidade dos leitores da época, justamente no caráter privado da experiência que originou a narrativa. Por outro lado, isso levava a que gestos isolados fossem abordados pelos viajantes como instantes representativos de toda uma experiência cultural uma espécie de indutivismo radical.

Sobre essa questão é interessante observar o que diz Miriam L. Moreira Leite (1997, p. 21), ao fim de sua extensa pesquisa sobre os viajantes. A autora conclui que, "à parte os exageros, preconceitos da ciência do tempo dos autores, de sua posição social e política, todos transmitem experiências sociais a partir de experiências individuais". Assim, a leitura atual dos viajantes precisa considerar que esses textos não raro generalizam demasiadamente, valendo-se por vezes da menção a um evento pontual para a construção de uma verdade que tende à universalidade. "Por um gesto", diz a autora, muitas vezes o viajante "julga um caráter, por um caráter avalia um povo". Essa dimensão das narrativas, também retomada por Tânia Quintaneiro (op. cit., pp. 24-5), lembra ao historiador o quanto as vozes que interrogamos não apenas nos falam de uma ou outra experiência, mas a constituem. Interessa registrar, como contraponto ao argumento de Miriam L.M. Leite, o estudo de Tânia Vergara (op. cit.), quando esta enfatiza, em referência a T. Todorov, que os viajantes poderiam promover um deslocamento dessa lógica cultural de priorização unilateral de sua cultura de 
origem. Estudando Flora Tristan, "uma das feministas e socialistas pioneiras da geração de 1830 na França", Vergara indica que aquela viajante saía em busca de outros lugares justamente para investigar experiências culturais diversas, a fim de desarticular generalizações que tomassem por justa e correta apenas a lógica cultural européia.

De uma forma ou de outra, considera-se aqui a idéia de que os viajantes pensaram o Brasil a partir das lentes conceituais de sua época. As narrativas esboçadas por eles podem ser exploradas, portanto, não apenas como registro de um tempo que se afasta do nosso mas, principalmente, como uma demonstração das formas pelas quais, naquelas circunstâncias, se davam tais práticas de memorização do vivido. Sua produção, enfim, se deu em meio a relações bastante singulares entre o Velho e o Novo Mundos, e elas não eram imunes aos regimes de dizibilidade de seu tempo. Não podemos esquecer, portanto, que as operações simbólicas e os mecanismos de significação que constroem os textos dos viajantes ganham em inteligibilidade quando são considerados parte de um diálogo mais amplo, com mais implicações (políticas, estéticas etc.) do que se pode pensar, à primeira vista (Belluzzo, op. cit., p. 10; El Far, 2000; Rodrigues, op. cit.; Vergara, op. cit.).

\section{Um recorte na narrativa de Thomas Lindley}

Conforme afirmamos anteriormente, não será feita aqui uma análise da narrativa integral de Lindley, mas apenas de seu relato sobre o cotidiano das doenças e dos seus tratamentos. Como vários outros viajantes que percorreriam o Brasil ao longo do século XIX, Lindley destacou, em diversas passagens de seu texto, uma das dimensões mais evidentes da experiência social brasileira de então: a questão da "fragilidade da vida humana". Esta veio a ser uma das temáticas mais presentes nas narrativas dos viajantes e memorialistas do século XIX, uma época em que era demasiado "alto o índice de morbidade e de mortalidade", e em que não eram apenas os males comuns e corriqueiros que incomodavam a população. O Brasil foi especialmente vitimado por sucessivas epidemias ao longo daquele século: as "febres e o cólera dizimaram arraiais em pânico, já castigados pela multiplicação de casos de bócio, cegueira e tuberculose, afora as doenças infantis e adultas de que não se conheciam as causas" (Leite, op. cit., p. 23). A morte era uma presença constante, tanto quanto o enfraquecimento dos corpos, atacados por moléstias sem conta (David, 1996; Reis, 1991; Soares, op. cit.).

Confundido com um médico pelos 'naturais', o texto de Lindley constitui uma fonte valiosa de questões sobre a saúde e a doença na experiência social brasileira daqueles anos.

Quando o meu brigue aportou pela primeira vez em Porto Seguro, fui visitado pela quase totalidade dos moradores do local, ignorantes que pareciam macacos a espiar tudo. E mal deram com minha caixa de 
remédios, indagaram de que era, e julgaram, certa ou erradamente, que eu deveria ser médico, e, sendo estrangeiro, sem dúvida médico famoso (Lindley, op. cit., p. 44).

A partir desse equívoco uma sucessão de eventos foi desencadeada, e ele tornou-se observador privilegiado das relações que os brasileiros mantinham com a experiência do adoecimento e com os mecanismos de significação e subjetivação aí operados. Em uma ocasião, quando ainda era apenas um mercador no navio que o trouxera, ele passou a atender a quem lhe procurava, até que foi impedido por uma circunstância infeliz:

Antes de cair a noite, várias canoas encostaram no navio, transportando doentes, estropiados e cegos, todos sofredores e pobres (segundo diziam), alguns suplicando pelo amor de Deus, outros implorando em nome de Maria, Nossa Senhora. Como logo estabeleci o sistema da gratuidade, eles jamais me permitiram acabar com aquilo, até que, visitando um pobre homem atacado de febre maligna, caí doente, e, por felicidade, perdi toda a clientela (idem, ibidem, p. 44).

Após sua prisão, entretanto, a peregrinação continuaria:

Agora são os clientes de novo, numerosos como nunca, não obstante estar eu proibido de falar com qualquer pessoa. Cada sentinela sofre de algum mal ou traz-me parente, vizinho ou amigo enfermo, além de outras criaturas que obtêm permissão do comandante para esse fim. Em resumo: multiplicaram-se tão rapidamente as consultas, reduzindo o conteúdo de minha pobre caixa, que o Senhor Tamás (nome que me dão) gostaria de nunca ter-se atribuído o ofício de curar ou, pelo menos, havê-lo exercido de modo mais profissional, sendo bem pago pelos seus remédios (idem, ibidem, 44-5).

Mesmo preso, como se vê, Lindley agia como médico. Pensa em desistir, mas não há como fugir do seu destino: como explicar, em meio às suas atividades, que jamais havia sido médico? Já era uma personalidade pública, graças ao seu 'saber'. Como abrir mão disso? Por outro lado, sua nova identidade permitia-lhe não apenas uma maior motilidade, como veremos a seguir, com o conseqüente alargamento da condição de observador da realidade local, mas também lhe servia para demarcar a incivilidade local. Como os brasileiros se deixaram enganar, tomando por médico um comerciante? Lindley acaba por construir, em sua narrativa, um libelo contra a medicina colonial, não apenas discorrendo acidamente contra os métodos terapêuticos aqui praticados, mas também desqualificando os médicos locais, ao conseguir se passar de modo fraudulento por um desses profissionais sem ser habilitado para tal (Reis; Soares, - op. cit.).

É interessante observar as várias restrições de sua condição, afinal era prisioneiro sob acusação grave, sendo-lhe vetada uma série de 
possibilidades de comunicação e deslocamento. No entanto, quando se tratava de uma ação como profissional da saúde, era-lhe determinado, pelo próprio chefe da guarnição em que estava preso, que ele ganhasse o mundo. Em 13 de agosto de 1802 lemos o seguinte registro em seu diário:

O comandante pediu-me que fosse ver um doente, num vilarejo além da cidade. Lá segui eu, acompanhado de um soldado, e o paciente era o Sr. Rodrigues da Fonte, de quem eu já ouvira falar. Tinha ele na véspera sofrido um ataque de apoplexia; percebi que estava muito mal, com a respiração ofegante e difícil, o pulso fraco e irregular, por vezes parando de bater. A medicação tópica e interna que ousei aplicar não produziu o menor efeito, havendo a natureza perdido toda a sua força e energia (Lindley, op. cit., p. 45).

A seguir Lindley retrata uma das formas de morrer na Colônia, não sem manifestar espanto ou crítica:

Estava o pobre homem num quarto fechado onde não penetrava o ar puro e a luz; apenas uma vela era mantida sobre sua cabeça, enquanto ele jazia imóvel numa grande cama, que ocupava um canto do aposento, a cabeceira e um lado encostados na parede. Entre esta e o doente havia um certo espaço onde sua mulher e outras criaturas do sexo feminino se acocoravam, passando por cima do corpo do homem, quando era preciso. Na parte superior da cama estavam colocadas diversas pequenas imagens, uma perna, um pé, um espadim e outras relíquias. Uma coroa de madeira trançada era sempre mantida suspensa sobre o pobre homem, e o conjunto formava a mais curiosa mistura de moléstia, estupidez e superstição. O aposento, cheio de parentes, visitas e criados, estava muitíssimo quente e abafado; senti-me feliz ao deixá-lo, pois, nas condições atuais do desgraçado, minha permanência ali não poderia ser de qualquer utilidade (idem, ibidem, p. 45).

A morte do doente, no dia seguinte, não surpreendeu Lindley. Tampouco fez diminuir sua clientela. No dia 4 de setembro novo paciente lhe foi trazido, e o infeliz inspirou Lindley a insinuar um paralelo entre os cuidados para com o paciente anterior, abastado, e os destinos de um pobre criado:

Um sargento trouxe-me a solicitação do comandante para que eu tentasse curar um membro de sua criadagem, o qual foi logo depois conduzido ao quarto contíguo ao meu e jogado a um canto, como se fosse um montão de lixo. Verifiquei estar com febre alta, visivelmente às portas da morte; e indagando sobre o caso, fui informado de que se achava doente havia já vinte e sete dias, acamado na Casa da Guarda, piorando sempre e inteiramente abandonado até aquele momento. Acomodei o pobre desgraçado numa esteira; e depois de ministrar-lhe um tônico fiquei aguardando que esse surtisse efeito (idem, ibidem, p. 50). 
A participação de um padre no ofício da cura desse "pobre desgraçado" foi descrita duramente por Lindley:

Mal o homem se havia deitado uns dez minutos, chegou um padre para confessá-lo. Fazendo todos saírem do quarto, sentou-se ao lado do penitente. Não satisfeito com esse esforço a que o submeteu, declarou ser absolutamente necessário ministrar-lhe a comunhão, o que foi feito com todas as formalidades. E como se estivesse determinado a não dar tréguas àquele organismo exausto, deu-lhe ainda a extrema-unção: retirou do bolso uma pequena caixa de prata, contendo certo ungüento verde (previamente bento) e, com uma espátula, extraiu pequena quantidade dele, espalhando-a nas sobrancelhas, lábios, narinas, orelhas, testa, sola dos pés, palmas das mãos e costas do doente, repetindo uma breve oração após cada etapa, e encerrando a cerimônia com outras preces (idem, ibidem, p. 50).

O padre, ciente da reprovação, por parte do inglês, de sua intervenção, justificou seu ritual com um argumento teológico que não convenceu Lindley:

Diante de minha censura por haver sido tão intempestivo numa ocasião daquelas, declarou o padre-fantasma que o pecador, livrado de todas as influências demoníacas sobre suas funções corpóreas, poderia ser entregue aos efeitos da própria constituição. Agora, era perfeitamente irrelevante que morresse ou sarasse (idem, ibidem, p. 51).

Enquanto registrava o que ia ocorrendo, dia após dia, no seu cativeiro, Lindley também se dedicava a assinalar o que, para ele, eram costumes estranhos e dignos de nota - sobretudo porque, além de singulares, eram comuns aos homens e mulheres da terra brasileira. Registrou o seu espanto, por exemplo, diante do hábito geral de os indivíduos catarem piolhos uns dos outros, em qualquer momento e sem nenhuma cerimônia. Mas não apenas esse costume surpreendeu o inglês; ele menciona também o seu desagrado quanto às relações que a população mantinha com uma doença cutânea "julgada sobremodo vergonhosa" pelo povo inglês, "até mesmo entre as classes mais baixas", mas que, no Brasil, nem de longe se passa como o "opróbrio insultuoso" que representa para os "naturais do norte". Falava ele da sarna, algo que "no Brasil é um mal geralmente confessado, não estando a ele associada a menor idéia de vergonha ou desgraça". Nosso autor arriscou uma explicação para essa desavergonhada visibilidade da moléstia entre os brasileiros:

Talvez a sua extensão seja a razão disso, pois quase ninguém dele escapa: e até mesmo as senhoras exibem seus delicados dedos, queixando-se de sarna. A cura desse padecimento é raramente tentada, até que, afinal, ele se fixa sob a forma de uma 'lepra' 
escamosa, especialmente no ventre dos homens, cujas camisas têm aberturas laterais, quando estãoà vontade, para que se possam coçar mais facilmente, arregaçando as mangas até os cotovelos. E o fazem diante de qualquer um, publicamente e sem pejo, considerando-o sinal de estarem a gosto, semcerimônia, em casa (idem, ibidem, p. 53).

Em meados de setembro de 1802, Lindley registrou "algo de extremamente pernicioso na atmosfera". Todos pareciam ser afetados, "sofrendo de ligeira febre e dores de cabeça". O inglês dizia ser "inacreditável o número de enterros, considerada a população". Assim, ele praticava algo comum à lógica científica de seu tempo: a associação entre a geografia e a medicina. Alguns lugares seriam mais susceptíveis do que outros a certas moléstias, devido às suas condições climáticas (Reis, 1991). Mas, em sua opinião, algo além de uma simples alteração atmosférica estava relacionado ao aumento das mortes; e sua explanação também revela uma avaliação da terapêutica da época (cf. Gonçalves, 1999; Soares, op. cit.):

A varíola faz aqui terríveis devastações, assim como outras moléstias, principalmente devido à maneira imprópria com que são tratadas, sendo as sangrias e os clisteres de leite humano os grandes específicos. ... por qualquer padecimento sem importância, tira-se o sangue do paciente duas ou três vezes; e nos casos de afecções sérias, oito ou dez. Visitei um pobre diabo que havia sido sangrado vinte e uma vezes em nove dias, por causa de uma dor no peito. Encontrei-o à morte, naturalmente.

Censurei esse procedimento absurdo e tentei convencer os homens da insensatez de recorrerem assim indiscriminadamente a operação tão séria como a flebotomia. Mas raramente os preconceitos são erradicados com facilidade, e não espero aconteça o contrário, neste particular (Lindley, op. cit., p. 54).

A narrativa de Lindley não registra o perfil dos profissionais que tratavam da saúde das pessoas na região em que ele transitou durante sua estada no Brasil. A literatura especializada, no entanto, nos indica que por aqueles anos o Brasil entregava seus doentes aos físicos ou licenciados - formados por escolas médicas européias, pois só teríamos as nossas após 1808 - , ou aos cirurgiões-barbeiros, que compunham a maior parte do grupo. A esses últimos cabiam as práticas de sangria, sarjadura, aplicação de ventosas, extração de dentes e cirurgia, mas acabavam por praticar toda a medicina, em virtude da carência de físicos. Licurgo Santos Filho retrata os cirurgiões-barbeiros com dureza: "Sem qualquer instrução, de baixa condição social, entre os barbeiros contavam-se negros escravos e mulatos libertos" (Santos Filho, 1968, p. 149; cf. Gonçalves, op. cit.; Rodrigues, op. cit.).

Sendo imensa a colônia e parcos os recursos, os meios de se recobrar a saúde eram precários e difíceis. O quadro estimulava a 
proliferação de alternativas, nem sempre recuperadas com muita simpatia por certa história:

Sendo poucos os profissionais habilitados e muito vasta a extensão territorial, juntamente com eles [físicos e barbeiros] praticavam a medicina ainda os boticários e seus aprendizes, os aprendizes de barbeiros e de cirurgiões-barbeiros, os 'anatômicos', os 'algebristas', os 'curandeiros', os 'entendidos', 'curiosos' e outros que tais (Santos Filho, op. cit., p. 149).

Lindley, imerso em tal cenário, via os métodos da medicina local como um amontoado de preconceitos. Em nada se aproximavam daquilo que, para ele, era a verdadeira arte de curar, tal como praticada pelos médicos de sua terra natal. Para a construção dessa percepção desabonadora da colônia deve ter contribuído, certamente, o contato freqüente do autor com práticas mágicas, comuns à população mas absolutamente estranhas à lógica de Lindley (Reis, op. cit.). Ele havia se referido aos talismãs que encimavam a cama de um doente, e logo adiante também menciona o costume do uso de ornamentos mágicos pelo corpo:

A senhora do capitão Veloso ostentava uma coleção completa desses enfeites, ao passo que uma pobre mulher, que viera a negócios, usava simplesmente um fio de ouro com dois escapulários de seda. Esses escapulários não têm mera finalidade religiosa; servem também de invólucros para feitiços, que curam ou impedem certas doenças e aliviam padecimentos graves. Não sei se os cidadãos adotaram tal superstição dos negros da Guiné, seus escravos, ou se existe outra causa que a explique. Mas são geralmente dados a essa prática (Lindley, op. cit., p. 64).

Não deixa de ser interessante um paralelo entre as palavras de Lindley e o texto de Licurgo Santos Filho. Este último, tratando mais especificamente do início do século XIX, assim afirma:

A medicina praticada e exercida nessa fase ... refletiu apenas, no que pode, a súmula de noções, idéias e preceitos então em voga nos centros europeus, dos quais proveio. ... Advirta-se, entretanto, que embora originária da européia, a arte médico-cirúrgica trazida para o Brasil experimentou o toque da terra, do ambiente, sofrendo, ademais, a influência dos agentes incultos, ou inscientes, que a veicularam. Constituiu ela, então, mormente na base agora encarada, má expressão da ciência da época, pois que foi bem pouco conhecida e bem mal praticada, estando ainda prenhe de abusões e superstições (Santos Filho, op. cit., p. 145).

Em certa ocasião, vítima de uma febre grave e de calafrios que não se deixavam curar, Lindley foi instado a valer-se da 'superstição' dos naturais do lugar, adotando uma mescla de elementos mágicos e 
heranças da fé cristã. Essa circunstância valeu-lhe o aprendizado de que a inclusão numa cultura implica a partilha de seus códigos e gestos; uma recusa poderia ser entendida como um agravo às boas relações, ainda mais naquele mundo, em que o tratamento dos males do corpo era quase que universalmente realizado mediante o uso de "fórmulas secretas, triagas e panacéias", além de "antídotos, talismãs, amuletos, acompanhados de rezas e palavras mágicas com a invocação do sobrenatural" (Santos Filho, op. cit., p. 152). A experiência de ceder a tais costumes permitiu também a Lindley aproveitar-se do fato para criticar, ao mesmo tempo, uma prática local e alguns hábitos ingleses, por ele equiparados com a incivilidade colonial:

Um senhor de Caravelas ofereceu-me certo feitiço infalível, que os dissiparia [os calafrios] imediatamente. Recusei-o; ele insistiu com uma tal veemência que cedi à sua oferta, para evitar ofendê-lo. Escreveu imediatamente o feitiço num papel de formato curiosamente triangular: eu deveria usá-lo junto ao coração e, diariamente, ao meio-dia, repetir determinado número de ave-marias, padre-nossos e glórias, tendo o cuidado de jamais deixar de usá-lo, sob pena de voltar o meu mal. Gostaria de ter inserido aqui este específico infalível para o bem daqueles meus leitores ingleses que são por demais ludibriados por imposturas análogas, disfarçadas em pílulas ou pós que nunca falham. Acredito que os dois feitiços, o brasileiro e o inglês, prestam iguais serviços. Mas aquele é mais inocente. Infelizmente, porém, para os ingleses e para mim, ele foi apreendido com os meus outros papéis, e nunca mais restituído (Lindley, op. cit., p. 64).

Os modos de funcionamento da medicina colonial eram, para Lindley, um exemplo evidente do atraso e dos equívocos aqui existentes em matéria de prática curativa. Licurgo Santos Filho (op. cit., p. 145) estabeleceu uma justificativa para esse "atraso" da medicina colonial que, certamente, não seria desmentido pelo viajante inglês:

É a partir do século XVI que se iniciam, na Europa, investigações, estudos e descobertas que irão proporcionar à medicina o cunho científico de que passou a se revestir. E tais investigações e pesquisas não se efetuaram e também não penetraram com facilidade nos centros ibéricos, como Salamanca e Coimbra, onde justamente estudaram os físicos e cirurgiões que até fins do século XVIII exerceram a profissão no Brasil. Ainda incipiente como ciência na maioria dos centros civilizados e até mesmo mal-aplicada pela generalidade dos profissionais, não é de admirar que a medicina, em suas idéias e como arte, viesse a decair transplantada para meio adverso e praticada por indivíduos ignorantes, de índole aventureira, desafeiçoados aos estudos, dado que para as terras americanas não emigraram médicos de saber, de cultura, e muito menos professores ou pesquisadores. 
Mas, como vimos, Lindley não apenas desqualificava a medicina brasileira; ele a usava, por outro lado, como referência para criticar costumes ingleses dignos de repúdio, por se aproximarem de hábitos tão pouco civilizados como os dos homens da colônia. Para isso, pois, também serviam os relatos dos viajantes: suas narrativas estabeleciam contra-exemplos para seus leitores europeus ou norte-americanos, os quais deveriam construir seus códigos de modo a que fossem opostos aos observados nos povos do além-mar (Soares, op. cit.).

As posições de Lindley contra a medicina aqui praticada seriam abrandadas quando, em meados de novembro de 1802, cada vez menos esperançoso de alcançar a liberdade ou a completa devolução de seus bens - capturados pelas autoridades coloniais - e a conselho do próprio governador, aceitou fingir-se de doente para minorar sua pena:

... Sua Excelência pretendia conceder-nos liberdade de movimentos, dentro dos limites da cidade. Para que eu conseguisse tal mercê, ... ele (o governador) aconselhava-me a fingir que estava doente, obtendo, para esse fim, atestados de um médico e de um cirurgião, prontos a declarar que a minha vida correria perigo se eu permanecesse enclausurado no forte (Lindley, op. cit., p. 82).

E assim foi feito. Os senhores João Dias da Costa, cirurgião, e Isidoro José de Lima, médico, "ambos ilustres na cidade", atestaram, "pelos Santos Evangelistas",

... que o Sr. Thomas Lindley estava violentamente atacado de um calor generalizado pelo corpo, o qual the produzira hemorróidas, além de afetar-lhe de outras maneiras todo o sistema, pondo sua vida em perigo; e que a liberdade de transferir-se para a cidade, a fim de obter os conselhos e o conforto proporcionados pelo lugar, era absolutamente necessária ao caso, para evitar mais graves conseqüências! (idem, ibidem, p. 82)

Mesmo em liberdade, Lindley persistiu na sua observação pouco amistosa dos costumes coloniais. A forma como os medicamentos eram obtidos pelos próprios comerciantes especializados foi outra fonte de espanto para Lindley. Custou-lhe acreditar, homem já apresentado ao novo mundo que o progresso técnico estava introduzindo na Europa, que um mister tão importante não ficasse inteiramente sob o encargo de alguém especializado, com experiência chancelada pelo saber formal (cf. Gonçalves, op. cit.; Soares, op. cit.; Rodrigues, op. cit.; Vergara, op. cit.):

Indaguei na casa de um amigo (farmacêutico) sobre a possibilidade de arranjar alguém que me acompanhasse às matas para que eu pudesse colher observações a respeito de plantas medicinais. Fiquei surpreendido ao saber que ele próprio as obtinha por compra a escravos e índios mestiços, que as ofereciam à venda. E ninguém, na Bahia, adotava outro processo (Lindley, op. cit., p. 99). 
O mundo em que Lindley havia sido capturado o assustava. Se a mata brasileira, por um lado, era fonte de fascínio para o europeu de sensibilidade porosa ao maravilhoso, por outro constituía um manancial inesgotável de surpresas. E - por que não dizer? - era um lugar de medo, em face do desconhecido absoluto que, de certa forma, representava. Foi difícil para o inglês, conforme seu relato, aceitar aquilo que Licurgo Santos Filho (op. cit., p. 151) assim descreveria:

As plantas medicinais nativas constituíram o maior arsenal terapêutico empregado. Já conhecidas dos indígenas e por eles usadas, aproveitadas pelos padres, que as difundiram, os demais profissionais da medicina delas se valeram no seu receituário. Acresce que os medicamentos reinóis ou europeus que os físicos carregavam nas suas caixas de botica, além de não bastarem para o consumo - e a importação mostrou-se precária e morosa - deterioravam-se com facilidade.

Vê-se no texto de Lindley um cenário em que doenças e morte eram banais. Os brasileiros são descritos como insensíveis aos males comuns, pelo que estes tinham de corriqueiros. Ou, talvez, o pouco apego à vida humana dirigisse as relações entre os sujeitos, mesmo em situações chocantes. O inglês relatou ter presenciado, no início de junho de 1803, uma ação militar na Bahia voltada para o recrutamento de novos "marinheiros para um navio de setenta e quatro toneladas, recémconstruído". Soldados armados recolhiam homens pelas ruas, "com toda a brutalidade que requer tal infração dos direitos da humanidade". Em meio a isso, alguém cai, e o que ocorre em seguida impressiona o inglês:

Um pobre marinheiro atraiu particularmente minha atenção. A surpresa da captura fê-lo cair em convulsões enquanto era conduzido pela rua. Estava deitado, em estado de aflição extrema, batendo com a cabeça nas pedras, enquanto o soldado dele encarregado permanecia de pé, com a mais fria indiferença, aguardando que ele recuperasse os sentidos. E o que achei igualmente cruel, a multidão que se aglomerou não prestou o mínimo socorro ao homem; dando de ombros, olhava e seguia adiante (Lindley, op. cit., p. 138).

Na parte final de seus escritos, Lindley dedicou-se a descrever Porto Seguro e Bahia mais minuciosamente. A essa altura, buscou resumir suas impressões de forma mais sistemática, recorrendo às informações dispersas na anotações quase diárias registradas até então, para compor quadros que definiam em termos concisos a impressão geral que a terra lhe causava.

Sobre a salubridade ele diria, numa última imagem do Brasil e como derradeira mensagem aos visitantes:

As febres predominam ao extremo através de toda a extensão dessas províncias, sendo mais graves e perigosas que em nossa 
terra. Poucos europeus escapam de seus ataques. Seguindo-se rumo ao sul, cresce a força do mal, e o lugar mencionado por último [São Mateus, "nos confins da capitania"] é tão fatal, que geralmente se torna o túmulo dos estrangeiros que o visitam (idem, ibidem, p. 156).

\section{Palavras finais}

Thomas Lindley, comerciante, contrabandista pelas leis portuguesas, fez-se médico ao sabor das circunstâncias; hoje, faz-nos pensadores de um sistema cultural estranho e fascinante.

Sua experiência curando - ou tentando curar - é uma densa metáfora, ainda a explorar, das relações que a nossa sociedade, desde tempos muito distantes do presente, vem permitindo estabelecer com 'o outro', notadamente com o 'outro' doente, e com o 'outro' que cura. Assim, ele nos faz pensar sobre o campo tenso dos encontros e desencontros entre colonizadores e colonizados, entre saberes chancelados pela academia e saberes populares, entre a pobreza, a riqueza e a doença, entre a fé e a razão etc. Eles são, parafraseando Regina Horta Duarte, "parte integrante da experiência vivida", "monumentos construídos pela sociedade da época" logo, territórios a explorar, a escavar (Duarte, 1995, p. 16).

Lindley nos leva a refletir, então, sobre a dura sorte dos seus contemporâneos, vítimas crônicas de um adoecimento naturalizado e de uma profusão de terapêuticas tão complexas quanto, para muitos, ineficientes. E nos faz pensar, também, acerca dos modos pelos quais a experiência da doença, naquelas circunstâncias, servia, por exemplo, para a demarcação mais incisiva de diferenças sociais, ou para a desqualificação incessante dos saberes cotidianos da população, por parte dos letrados ou desejosos por se fazer passar como tais. Seu texto igualmente permite cogitar os modos complexos pelos quais as sociedades incorporam, no seu cotidiano, saberes diversos, formas variadas de entendimento e de intervenção no mundo - muitas vezes fazendo dialogar, numa mesma prática, sentidos originalmente díspares ou mesmo antagônicos (Burke, 2000; Rodrigues, op. cit.).

Toda a sua narrativa se dá como um diálogo em suspenso, uma conversação entre seres que quase nunca se comunicam plenamente, ainda que por vezes o desejem. O relato de Lindley, como o dos demais viajantes, expressa uma tensão fundante, que faz da narrativa um complexo jogo de ressonâncias e de fraturas de sentido. Afinal, o narrador tratava de um mundo que the era alheio, e o relato foi produzido para uma leitura que se daria à distância em relação ao que estava sendo narrado - devendo, no entanto, impressionar os leitores, darlhes meios para a construção de novos lugares e de novos olhares sobre si e sobre o outro. Esta é uma dimensão dos livros de viagem a qual a análise não pode se furtar: 
Ao escreverem sobre nós, eles diziam também a respeito deles próprios, julgavam desde a perspectiva de sua sociedade, o pano de fundo contra o qual comparavam e avaliavam suas percepções, compreendiam e organizavam suas emoções, procuravam o sentido das experiências que viviam, mas principalmente situavam-se a si mesmos, expressando, reafirmando ou colocando em questão sua própria cultura (Quintaneiro, op. cit., p. 23).

Os viajantes nos levam a pensar sobre as formas pelas quais é possível operar essa tensão universal entre o mesmo e o outro, entre a identificação e o distanciamento. A apresentação dos personagens e dos eventos estabelece jogos de sentido em que gestos, posturas e mesmo algumas figuras - tomadas em bloco, a partir da idéia de que cada indivíduo ordena sua presença no mundo pela sua identidade essencial — não apenas representam dimensões positivas ou negativas da vida narrada mas, principalmente, indicam, pela sua existência mesma, ou seja, por aquilo que dela sabemos pelas palavras de seu narrador, possibilidades e impossibilidades para a vida social (Belluzzo, op. cit., pp. 10-3).

A narrativa dos viajantes, dentre elas a de Lindley, pode ser compreendida, nesse sentido, como uma operação cultural complexa, que compõe, ao mesmo tempo, um aparato de representações para o Brasil e um conjunto de referências para a identidade cultural do povo para quem se escreve. No relato, Lindley não apenas estava preocupado em traçar uma certa imagem da então colônia portuguesa mas, certamente, tinha no seu horizonte o desejo de educar a sensibilidade dos seus leitores para uma aproximação ou para um distanciamento em relação aos usos e costumes descritos.

São triangulações, jogos de espelhos que aí se organizam. É construído um mundo sobre o qual se narra, e é construído também um outro mundo para o qual se narra. E nesse movimento, duplo e complexo, são estabelecidas regras para a aproximação adequada (ou o afastamento necessário) entre essas duas realidades. Interrogar materiais dessa natureza, enfim, acaba por ser um exercício de reflexão sobre várias dimensões da sua historicidade: o que está neles representado? O relato dá ao leitor modelos a seguir ou a repelir? A partir de que referências as semelhanças e diferenças são problematizadas? (Belluzzo, op. cit., p. 10; El Far, op. cit.).

Estudar os viajantes tem, pois, sua importância. No dizer de Pedro M. Campos (1985, pp. 40-1), eles foram, entre outros, os responsáveis pela montagem da imaginação do resto do mundo sobre alguns instantes de nossa história, e esses movimentos merecem atenção. É imprescindivel lê-los, para sabermos como éramos vistos de fora - por discursos que, depois, seriam operados por nós mesmos na construção da nossa própria identidade. Igualmente, eles ajudam a compreender a dinâmica histórica do povo que nos observava: interesses "de ordem econômica, pendores filosóficos, predileções exóticas, a insatisfação com a realidade 
social e a ânsia de fuga para algo de melhor", tudo isso reverbera na construção que o outro faz de nossa experiência.

Lindley colocou-se o tempo inteiro em posição de confronto com os hábitos locais. A seu modo, ele se inseria num movimento habitual dos viajantes, em que esses personagens, dada a sua inserção singular na paisagem brasileira, acabavam por colocar, em perspectiva e de várias formas, para os próprios brasileiros, os usos e costumes da terra (Quintaneiro, op. cit., p. 20).

Hoje, à distância, Lindley parece nos perguntar, entre tantas outras questões: como vocês adoecem? A quem vocês entregaram os cuidados do corpo? Qual o papel social do doente, do são, do médico, do religioso? E, finalmente, quais as coordenadas (éticas, políticas, técnicas) que demarcam o lugar a partir do qual vocês constroem e operam suas respostas? (El Far, op. cit.).

\section{REFERÊNCIAS BIBLIOGRÁFICAS}

Alencastro,

Luiz Felipe de $1997 \mathrm{a}$

Alencastro,

Luiz Felipe de $1997 b$

Belluzzo, Ana Maria jun.-ago. 1996

Burke, Peter

2000

Campos, Pedro Moacyr 1985

Canesqui,

Ana Maria (org.) 1997

Darnton, Robert 1986

David, Onildo Reis 1996

Duarte, Regina Horta 1995

El Far, Alessandra 2000

Ferri, Mário Guimarães 1975
'Introdução: modelos da história e da historiografia imperial'. Em Luiz Felipe de Alencastro (org.), História da vida privada no Brasil: Império.

São Paulo, Companhia das Letras, pp. 7-11.

'Vida privada e ordem privada no Império'. Em Luiz Felipe de Alencastro (org.), História da vida privada no Brasil: Império.

São Paulo, Companhia das Letras, pp. 11-93.

'A propósito d'O Brasil dos Viajantes'.

Revista USP, 30, pp. 8-19.

Variedades de história cultural.

Rio de Janeiro, Civilização Brasileira.

'Imagens do Brasil no Velho Mundo'. Em Sérgio Buarque de Holanda (org.),

História geral da civilização brasileira, t. II, v. 1, pp. 39-63.

Ciências sociais e saúde.

São Paulo, Editora Hucitec/ABRASCO.

O grande massacre de gatos.

Rio de Janeiro, Graal.

O inimigo invisível: epidemia na Babia no século XIX. Salvador, Sarah Letras/ EDUFBA.

Noites circenses: espetáculos de circo e teatro em Minas Gerais no século XIX. Campinas, Editora da Unicamp.

'O uso da antropologia hermenêutica por Robert Darnton'. Em Lília M. Schwarcz e Nilma Lino Gomes (org.), Antropologia e bistória: debate em região de fronteira. Belo Horizonte, Autêntica, pp. 53-70.

'Apresentação'. Em George Gardner, Viagem ao interior do Brasil, principalmente nas provincias do Norte e nos distritos do ouro e do diamante durante os anos 1836-1841. Belo Horizonte, Itatiaia, São Paulo, Editora da Universidade de São Paulo, pp. 9-10. 
Gonçalves,

Betânia Figueiredo jul.-out. 1999.

Lacombe,

Américo Jacobina

1969

Leite, Miriam L. Moreira

1997

Lindley, Thomas

1969

Manthorne, Katherine E. jun.-ago. 1996

Pinho, Wanderley

1969

Quintaneiro, Tânia 1995

Raeders, Georges 1996

Reis, João José 1991

Rodrigues, José Carlos 1999

Santos Filho, Licurgo 1968

Soares, Márcio de Sousa jul.-ago. 2001.

Vergara, Moema

de Rezende

1998
'Barbeiros e cirurgiões: atuação dos práticos ao longo do século XIX'.

Histórias, Ciências, Saúde - Manguinhos, vol. 6(2), Rio de Janeiro.

Disponível em www.scielo.br./hcsm.

'Narrativa de uma viagem ao Brasil' (texto de orelha). Em Thomas Lindley, Narrativa de uma viagem ao Brasil. São Paulo, Companhia Editora Nacional.

'A infância no século XIX segundo memórias e livros de viagem'. Em Marcos Cezar de Freitas (org.), História social da infância no Brasil. São Paulo, Cortez; Bragança Paulista, USF-IFAN, pp. 17-50.

Narrativa de uma viagem ao Brasil.

São Paulo, Companhia Editora Nacional. (Edição original de 1805.)

'O imaginário brasileiro para o público norte-americano do século XIX'. Revista USP, 30, pp. 58-71.

'Prefácio'. Em Thomas Lindley, Narrativa de uma viagem ao Brasil. São Paulo, Companhia Editora Nacional, pp. 7-13.

Retratos de mulher: a brasileira vista por viajeiros ingleses $e$ norte-americanos durante o século XIX. Petrópolis, Vozes.

O Conde de Gobineau no Brasil. Rio de Janeiro, Paz e Terra.

A morte é uma festa: ritos fúnebres e revolta popular no Brasil do século XIX. São Paulo, Companhia das Letras.

O corpo na história.

Rio de Janeiro, Editora Fiocruz.

'Medicina colonial'. Em $H G C B$, t. I, 2. vol.

São Paulo, Difel, pp. 143-60.

'Médicos e mezinheiros na Corte Imperial: uma herança colonial'.

História, Ciências, Saúde - Manguinhos, vol. 8 (2), pp. 407-38.

Disponível em www.scielo.br.

'A figura da viajante: as peregrinações de Flora Tristan'.

LOCUS, revista de história, 4:1, pp. 39-52. 